Metodički obzori 7(2012)2

Original research paper

UDK: 376.1-058.51:373.34](497.5Pula)

Received: 13.10. 2010.

\title{
DIFFERENCES IN MALE AND FEMALE PUPILS' SELF-ASSESSMENT OF BEHAVIOUR DISORDERS
}

\author{
Iva Blažević, PhD \\ Elementary School Vidikovac in Pula (Croatia) \\ e-mail: idobrila@yahoo.com \\ Mirjana Radetić-Paić, $P h D$ \\ Department of Educational Sciences, \\ Juraj Dobrila University of Pula (Croatia) \\ e-mail: mradeticpaic@ hotmail.com \\ Prof. Vesna Babić, PhD \\ Faculty of Kinesiology, \\ University of Zagreb (Croatia) \\ e-mail: vesna.babic@kif.hr
}

\begin{abstract}
S u m m ary
The aim of this research is to define the differences between male $(\mathrm{N}=121)$ and female $(\mathrm{N}=121)$ pupils' self-assessment of behaviour disorders. The pupils belonged to the fifth, sixth, seventh and eighth forms of the Elementary School Vidikovac in Pula. The existence of differences between sexes is based on the assumption that different sexual roles like rebelliousness, nonconformism and disregard of norms are more typical for the male sexual role in our cultural environment, as well as in the school environment.

The results have shown that differences between male and female pupils exist when it comes to behaviour disorders. The above stated points point to the need for registering such indicators in the school environment and including this knowledge in the production of different preventive programmes and enabling different approaches to groups of male and female pupils.
\end{abstract}

Key words: behaviour disorders, male pupils, female pupils, school, selfassessment, Pula

\section{Introduction}

The theory about sexual selection (Pawlowski, Atwal and Dunbar, 2008) predicts that male persons have the tendency to behave in riskier ways than female persons. Various studies came to the conclusion that young males are more prone to behave in a riskier way than females, such as conflicts (Campbell, 1999; Daly and 
Wilson, 1988; Wilson and Daly, 1993), drug abuse (Tyler and Lichtenstein, 1997) and out-of-home activities (Howland and partners, 1996; Wilson and partners, 1996). Psychological theories explain this phenomenon with the fact that female persons experience risky situations more stressfully than male (Kerr and Vlaminkx, 1997).

When it comes to differences between boys and girls in manifesting aggressive behaviour, researches have shown that girls use indirect methods of aggression like gossiping, exclusion and slandering. The rate of violence between girls becomes higher with the transition from secondary to high school, or in their adolescent period. Girls and boys use qualitatively different methods of aggression. Girls use verbal methods of aggression, while boys show physical violence (Prpić, 2006).

In a 2003 research conducted by the Polyclinic for the Protection of Children of the City of Zagreb (http://www.poliklinika-djeca.hr) pupils from 25 elementary schools from 13 Croatian cities were included. The obtained results showed that among the violent persons there were 33 percent of boys and 17 percent of girls. Sexual differences were not seen as significant for verbal violence. Both sexes used verbal violence towards others in an almost equal amount. At the same time, both sexes had the same tendency to use emotional violence.

Researches have also shown that sex determines a statistically important difference when it comes to unexcused absence from school (Nazor, 1997). Boys are more prone to unexcused absences. Such a cognition has, to an extent, its source in different sexual roles (Glavina-Kozić, 2002), but the reason for that can also be found in the subjective estimate of the form master. Namely, according to the results of some researches, teachers are more lenient towards female pupils, and they show a higher level of tolerance (Grgin, 1999).

In the school environment, boys show a poorer school success and more noticeable problematic behaviour (Šakić, Franc and Mlačić, 2002). By gaining sexual roles through the process of socialization, differences in the mechanisms of confronting school problems can be explained (Zrilić, 2007). For example, there are differences between sexes when it comes to facing test stress or bad marks (Brdar and Rijavec, 1997). Girls react by looking for a solution to problems (they study more for the next lesson, they try to correct the bad mark), while boys react emotionally (anger, argument, swearing) and try to avoid the situation (by playing truant). Klarin (2002) mentions a significant sexual difference when it comes to mechanisms of facing a bad mark. Girls, more often than boys, make use of the social support and blame themselves.

Literature points out that girls cooperate less and more commonly suffer from mental health disorders than boys. The possibility that of having suffered a significant trauma in their childhood is especially emphasized (Gavazzi, 2006; Gavazzi, Yarcheck and Chesney-Lind, 2006).

In the last ten years, as the number of underage female perpetrators of crime has grown (Snyder and Sickmund, 2006), the significance of sexual equality has gained more importance. 
In the context of recidivism, Funk (1999) has found out that there are differences between sexes, although the examined boys and girls had some common characteristics (for example, an earlier criminal history, social factors). Hanging out with delinquent peers and behaviour problems in school have influenced the higher risk recommitting crimes with boys, while childhood violence and running away from home are significant for a higher risk to recommit crimes with girls.

When it comes to sports activities, researches have shown that there are differences between boys and girls (Cimerman and Cetinić, 2008). Half of the boys practice sports occasionally, while 38 percent of them take active part in the work of sports clubs during the summer break. The results are somewhat poorer for the girls. Fifty-eight percent of them practice sports occasionally, and only 25 percent of them take active part in the work of sports clubs. Boys usually practice (42.5 percent) sport games (basketball, football, handball, volleyball and others) and individual activities (40 percent), while they don't show an interest for aesthetic activities (gymnastics, rhythmic gymnastics and ballet), sport games ( 7.5 percent) and contact sports, tennis and other sports like horse riding (each with 5 percent). Šiljković, Rajić and Berić (2007) notice differences between sexes on a younger population of elementary school pupils. Girls usually take part in extracurricular and out-of-school activities more often than boys, with the exception of sport activities.

On the other hand, when it comes to pupils' self-esteem or selfunderstanding, their importance stems out from their influence on the whole behaviour and experience of the young person. Self-understanding is a significant factor for the mental and social functioning of a young person, especially for the influence it has on the behaviour (Lacković-Grgin, 1994). It is known that positive or negative self-understanding widely influences the forming of a successful or unsuccessful identity, and along with that the everyday functioning, establishment of relationships, ways of solving problems or fulfilling one's own or other people's needs, achievement of happiness and others (Berger, 1979; Glasser, 1990; KollerTrbović, 1995).

\section{Aim, purpose and hypothesis}

The aim of this research is to define the differences between male $(\mathrm{N}=121)$ and female $(\mathrm{N}=121)$ pupils' self-assessment of behaviour disorders. The purpose of the research is to define the need of a differentiated treatment for male and female pupils with behaviour disorders or at risk of such behaviours in the school environment. The hypothesis is that statistically significant differences between male and female pupils' self-estimates about behaviour disorders are expected.

The hypothesis is based on the assumption that different sexual roles, like rebelliousness, nonconformism and disregard of norms, are more typical for the male sexual role in our cultural environment (Glavina-Kozić, 2002). On the other hand, the higher aggressiveness of boys is, to an extent, biologically determined by a higher amount of testosterones and by socialization factors like competition and the wish for domination in the group of male peers. 
A similar research (Raboteg-Šarić and Brajša-Žganec, 2001) has obtained results which show that boys have a statistically more significant amount of problematic behaviour in elementary and secondary school, drink more and perform worse at school. It has also been proved that externalized behaviour disorders are more present with boys in their earlier ages, while this difference becomes lower with age (Koller-Trbović, 2001).

\section{Methods}

\section{Sample of examinees}

The sample of examinees consisted of 242 pupils of the sixth, seventh and eighth forms of the elementary school Vidikovac. There were 121 male and 121 female examinees distributed according to forms and sex as follows:

- Fifth formers - 27 male and 27 female pupils

- Sixth formers - 38 male and 27 female pupils

- Seventh formers - 31 male and 43 female pupils

- Eighth formers - 25 male and 24 female pupils

\section{Sample of variables}

Behaviour disorders were estimated by pupils on the scale of the Likert type made of five degrees ( 1 - never, 2 - rarely, 3 - sometimes, 4 - often, 5 - very often). They estimated if, during the last thirty days, they performed actions which could be defined as behaviour disorders (problematic behaviour), or juvenile delinquency (deviant behaviour). Behaviour disorders (problematic behaviour) were defined based on some constructions which had been shown as important in the past researches for measuring various forms of such behaviour. The scales were constructed so that fragments from similar scales (Raboteg-Šarić and Brajša-Žganec, 2001) which had been used in similar researches (Berndt, 1979; Tyler and Lichenstein, 1997). Two sub-scales were formed in the final version, based on factor analysis: the scale of problematic behaviour (six fragments, $\alpha=.81$ ) and the scale of deviant behaviour (three fragments, $\alpha=.76$ ). Five fragments related to school conduct, school achievement, undertaking sports activities in one's free time, smoking and drinking were added.

The following fragments were assessed by the scale of problematic behaviour

1. performed acts of malevolence on the teacher

2. destroyed school property

3. went around teasing other children

4. beat and pushed others in the classroom

5. mocked others

6. lied or invented things to cause troubles to others 
The following fragments were assessed by the scale of deviant behaviour:

1. stole from other people

2. shoplifted

3. played truant

School conduct was assessed as:

1. exemplary

2. good

3. bad

School achievement included end-of-term success.

Performing sports activities was assessed by the following fragment:

1. in my free time I practice some sport fragments:

Experimenting with some addictive substances was assessed by the following

1. How often do you smoke cigarettes?

2. How often do you consume alcohol?

\section{Methods of data processing}

To determine the differences in self-assessment of behaviour disorders between male and female pupils, the discriminatory analysis and the univariant analysis of the variance were used.

\section{Methods for research carrying-out}

The research was carried out during 2010 in the elementary school Vidikovac in Pula by pupils filling in a questionnaire.

\section{Results of the research and discussion}

To determine the latent levels of differentiating male and female pupils, or to establish if there are, and if so, what the differences are between the examined groups, a discriminatory analysis was conducted. For the purpose of this research, the analysis was carried out on a group of variables based on which the selfassessment of behaviour disorders between male and female pupils was described. Since it was a discriminatory analysis of the two groups of examinees, a discriminatory function was obtained (Table 1) which is statistically significant at the level $\mathrm{p}=0.01$ and it discriminates the examined groups of examinees. 
Table 1. Variance analysis and the characteristic value for the discriminatory function

\begin{tabular}{|c|c|c|c|c|c|c|c|}
\hline Function & Eigenvalue & $\begin{array}{c}\text { Cumulative } \\
\%\end{array}$ & $\begin{array}{c}\text { Canonical } \\
\text { Correlation }\end{array}$ & Lambda & Chi-kvadrat & df & $\mathrm{p}$ \\
\hline 1 & 0,282 & 100 & 0,469 & 0,780 & 52,133 & 14 & 0,000 \\
\hline
\end{tabular}

By analyzing the discriminatory coefficients of the obtained function, its correlation with the discriminatory function (Table 2) and the position of centroids of the examined groups (Table 3), we come to the conclusion that the group of male pupils showed bad school conduct and smoked more often than the group of female pupils.

Table 2. Discriminatory coefficients and correlation with the discriminatory function

\begin{tabular}{|l|c|c|c|}
\hline & $\begin{array}{c}\text { Wilks' } \\
\text { Lambda }\end{array}$ & $\begin{array}{c}\text { Partial } \\
\text { Lambda }\end{array}$ & p-level \\
\hline school achievement & 0.782 & 0.998 & 0.546 \\
\hline school conduct & 0.870 & 0.896 & 0.000 \\
\hline sport & 0.780 & 1.000 & 0.901 \\
\hline malevolence & 0.781 & 0.999 & 0.658 \\
\hline destroyed & 0.783 & 0.996 & 0.374 \\
\hline teasing & 0.785 & 0.994 & 0.286 \\
\hline beat/pushed & 0.789 & 0.989 & 0.134 \\
\hline mocked & 0.784 & 0.995 & 0.324 \\
\hline lied & 0.786 & 0.993 & 0.216 \\
\hline stole from people & 0.787 & 0.991 & 0.180 \\
\hline shoplifted & 0.780 & 1.000 & 0.841 \\
\hline played truant & 0.786 & 0.993 & 0.218 \\
\hline smoking & 0.812 & 0.961 & 0.004 \\
\hline alcohol & 0.781 & 0.999 & 0.721 \\
\hline
\end{tabular}

Table 3. Functions on the group centroids

\begin{tabular}{|l|c|}
\hline & Function \\
\hline male pupils & 0.541 \\
\hline female pupils & -0.516 \\
\hline
\end{tabular}


Table 4. Results of the univariant analysis of variance

\begin{tabular}{|c|c|c|c|c|c|c|}
\hline & \multicolumn{2}{|c|}{ Mean } & \multicolumn{2}{|c|}{ Std. Deviation } & \multirow[b]{2}{*}{$\mathrm{F}$} & \multirow[b]{2}{*}{$\mathrm{p}$} \\
\hline & $\begin{array}{l}\text { male } \\
\text { pupils }\end{array}$ & $\begin{array}{l}\text { female } \\
\text { pupils }\end{array}$ & $\begin{array}{l}\text { male } \\
\text { pupils }\end{array}$ & $\begin{array}{l}\text { female } \\
\text { pupils }\end{array}$ & & \\
\hline school achievement & 3.978 & 4.126 & 0.873 & 0.738 & 1.92 & 0.17 \\
\hline school conduct & 1.621 & 1.311 & 0.538 & 0.533 & 19.66 & $0.00 *$ \\
\hline sport & 4.124 & 3.892 & 0.871 & 1.027 & 3.59 & 0.06 \\
\hline malevolence & 1.892 & 1.587 & 1.201 & 0.972 & 4.70 & $0.03 * *$ \\
\hline destroyed & 1.455 & 1.306 & 0.885 & 0.705 & 2.09 & 0.15 \\
\hline teasing & 2.174 & 1.851 & 1.145 & 1.038 & 5.26 & $0.02 * *$ \\
\hline beat/pushed & 2.124 & 2.017 & 1.053 & 1.080 & 0.61 & 0.43 \\
\hline mocked & 2.207 & 1.875 & 1.095 & 0.992 & 6.07 & $0.01 * *$ \\
\hline lied & 1.603 & 1.339 & 1.060 & 0.737 & 5.08 & $0.03 * *$ \\
\hline stole - people & 1.256 & 1.124 & 0.665 & 0.476 & 3.17 & 0.08 \\
\hline shoplifted & 1.215 & 1.157 & 0.635 & 0.592 & 0.54 & 0.46 \\
\hline played truant & 1.281 & 1.388 & 0.635 & 0.850 & 1.24 & 0.27 \\
\hline smoke & 1.050 & 1.283 & 0.218 & 0.832 & 8.93 & $0.00 *$ \\
\hline alcohol & 1.333 & 1.430 & 0.665 & 0.874 & 0.93 & 0.34 \\
\hline${ }^{*} \mathrm{p}<0,01$ & & & & & & \\
\hline
\end{tabular}

To gain an insight into the existence of possible differences between groups on manifest variables, Table 4 gives facts about arithmetic means, standard deviations of groups, the F-test and significance (p). The manifest variables school conduct and smoking are significant at the level of importance $\mathrm{p}<0.01$, and the variables mocked others, walked around teasing others, lied or invented to cause troubles to others and performed acts of malevolence on the teacher are significant at the level of importance $\mathrm{p}<0,05$.

\section{Conclusion}

The obtained results confirm the set hypothesis that statistically significant differences between male and female pupils in their self-assessments of behaviour disorders were expected. The results showed that differences exist because male pupils had bad school conduct and smoked more often than female pupils. This was also confirmed by the results of the research (Funk, 1999; Rabbani and Hossain, 1999; Raboteg-Šarić and Brajša-Žganec, 2001) in which boys were shown as those who expressed problematic behaviour at school, smoked or drunk more often than girls.

These facts also confirm the thesis about the socialization of children in a society which still divides everything to "male" and "female". Namely, it is known that girls are prepared for and taught caring and pro-social behaviours from an early childhood, while at the same time it is thought that such behaviour is not "male" enough (Bašić, Koller-Trbović and Žižak, 1993). 
Thus, differences between sexes, when it comes to behaviour disorders, do exist, and the above-mentioned results point to a need for evidencing these indicators in the school environment and including such knowledge in the production of different preventive programmes along with enabling different approaches to groups of male and female pupils.

\section{Bibliography}

1. Bašić, J., Koller-Trbović, N. i Žižak, A. (1993). Integralna metoda-teorijski pristup. Zagreb: Edukacijsko-rehabilitacijski fakultet Sveučilišta u Zagrebi i Alinea.

2. Berger, J. (1979). Psihodijagnostika. Nolit

3. Brdar, I., Rijavec, M. (1997). Suočavanje sa stresom zbog loše ocjene - konstrukcija upitnika. Društvena istraživanja, 6 (4-5), (30-31), 599-617.

4. Campbell, A. (1999). Staying alive: Evolution, culture and women's intrasexual aggression. Behavioural and Brain Sciences, 22, 203-267.

5. Cimerman, M., Cetinić, J. (2008). Interes djece i mladih za sportske aktivnosti tijekom ljetnih školskih praznika. 17. Ljetna škola kineziologa Republike Hrvatske „Stanje i prespetiva razvoja u području edukacije, sporta, sportske rekreacije i kineziterapije“, str. 94- 100. Poreč: Kineziološki fakultet Sveučilišta u Zagrebu.

6. Daly, M., Wilson, M. (1988). Homicide. Hawthorne, NY: Aldine de Gruyter.

7. Funk, S. J. (1999). Risk assessment for juveniles on probation: A focus on gender. Criminal Justice and Behaviour, 26, 44-68.

8. Gavazzi, S. M. (2006). Gender, ethnicity, and the family environment: Contributions to assessment efforts within the realm of juvenile justice. Family Relations, 55, 190-199.

9. Gavazzi, S. M., Yarcheck, C. M., Chesney-Lind, M. (2006). Global risk indicators and the role of gender in a juvenile detention sample. Criminal Justice and Behaviour, 33, 597-612.

10. Glasser, W. (1990). Pozitivna ovisnost. Edicija realitetne terapije. Br.4.

11. Glavina-Kozić, E. (2002). Izostanci u osnovnoj školi. Napredak, 43(3), 291-306.

12. Grgin, T. (1999): Školsko ocjenjivanje znanja. Jastrebarsko. Naklada Slap.

13. Howland, J., Hingson, R., Mangione, T.W., i Bell, N. (1996). Why are most drowning victims men? Sex differences in aquatic skills behaviours. American Journal of Public Health, 86, 93-96.

14. Kerr, J.H., Vlaminkx, J. (1997). Gender differences in the experience of risk. Personality and Individual Differences, 22, 293-295.

15. Klarin, M. (2002). Dimenzije obiteljskih odnosa kao prediktori vršnjačkim odnosima djece školske dobi. Društvena istraživanja, 11(4-5), (60-61), 805-822.

16. Koller-Trbović, N. (1995). Razlike u samoprocjeni slike o sebi djece s aktivnim i djece s pasivnim oblicima poremećaja u ponašanju. Kriminologija i socijalna integracija, 3 (1), 71-76.

17. Koller-Trbović, N. (2001). Prosudba rizika i potreba djece i mladeži s poremećajima u ponašanju u svrhu planiranja intervencija. U: Žižak, A., Koller-Trbović, N. i Lebedina-Manzoni, M., „Od rizika do intervencije“, str. 37-69. Zagreb: Edukacijsko-rehabilitacijski fakultet Sveučilišta u Zagrebu. 
18. Nazor, M. (1997). Izostanci s nastave, strah od škole i generalizirana samoefikasnost. Školski vjesnik, 46 (1) 31-35.

19. Pawlowski, B., Atwal, R., Dunbar, R.I.M. (2008). Sex Differences in Everyday RiskTaking Behaviour in Humans. Evolutionary Psychology, 6 (1) 29-42.

20. Poliklinika za zaštitu djece Grada Zagreba (http://www.poliklinika-djeca.hr) pristupljeno 12.travnja 2010.

21. Prpić, I. (2006). Vršnjačko nasilje među djevojčicama. Ljetopis socijalnog rada, 13(2), 315-330.

22. Rabbani, M.G., Hossain, M.M. (1999). Behaviour disorders in urban primary school children in Dhaka, Bangladesh. Public Health, 113(5), 233-6.

23. Raboteg-Šarić, Z., Brajša-Žganec, A. (2001). Roditeljski odgojni postupci i problematično ponašanje djece u ranoj adolescenciji. U: Bašić, J.; Janković, J. (ur.). „Rizični i zaštitni čimbenici u razvoju poremećaja u ponašanju djece i mladeži“, str.155-170. Zagreb: Povjerenstvo Vlade Republike Hrvatske.

24. Snyder, H. N., Sickmund, M. (2006). Juvenile offenders and victims: 2006 National Report. Washington, DC: U.S. Department of Justice, Office of Justice Programs, Office of Juvenile Justice and Delinquency Prevention.

25. Šakić, V., Franc, R., Mlačić, B. (2002). Samoiskazana sklonost adolescenata socijalnim devijacijama i antisocijalnim ponašanjima. Društvena istraživanja, 11(2-3), 265-289.

26. Šiljković, Ž. Rajić, V., Bertić, D.(2007). Izvan nastavne i izvanškolske aktivnosti. Odgojne znanosti, 9 (2),113-145

27. Tyler, J., Lichtenstein, C. (1997). Risk, protective, AOD knowledge, attitude, and AOD behaviour: Factors associated with characteristics of high-risk youth. Evaluation and Program Planning, 20, 27-45.

28. Zrilić, S. (2007). Neke potencijalno relevantne sociodemografske varijable školskih izostanaka. Odgojne znanosti, 9, (2), 41-65.

29. Wilson, M., Daly, M. (1993). Lethal confrontational violence among young men. In N.J. Bell and R.W. Bell (Eds.) Adolescent Risk-Taking (pp. 84-106). Newbury Park (CA), Sage.

30. Wilson, M., Daly, M., Gordon, S., and Pratt, A. (1996). Sex differences in valuations of the environment. Population and Environment, 18, 143-159. 
Metodički obzori 7(2012)2

Izvorni znanstveni rad

UDK: 376.1-058.51:373.34](497.5Pula)

Primljeno: 13.10. 2010.

\title{
RAZLIKE U SAMOPROCJENI POREMEĆAJA U PONAŠANJU UČENIKA I UČENICA
}

\author{
dr.sc. Iva Blažević \\ Osnovna škola „Vidikovac“ u Puli (Croatia) \\ e-mail: idobrila@yahoo.com \\ dr.sc. Mirjana Radetić-Paić, \\ Odjel za odgojne i obrazovne znanosti, \\ Sveučilište Jurja Dobrile u Puli (Croatia) \\ e-mail: mradeticpaic@ hotmail.com \\ prof.dr.sc. Vesna Babić \\ Kineziološki fakultet, \\ Sveučilište u Zagrebu (Croatia) \\ e-mail: vesna.babic@kif.hr
}

$S \boldsymbol{a}$ ž et $\boldsymbol{a} \boldsymbol{k}$

Cilj ovog rada je utvrđivanje razlika u samoprocjenama poremećaja u ponašanju između učenika $(\mathrm{N}=121)$ i učenica $(\mathrm{N}=121)$ petih, šestih, sedmih i osmih razreda Osnovne škole Vidikovac. Postojanje razlika među spolovima temeljena je na pretpostavci da su različite spolne uloge, kao buntovništvo, nekonformizam i nepridržavanje normi tipičniji za mušku spolnu ulogu u našoj kulturalnoj sredini, pa tako i u školskom okruženju.

Rezultati su pokazali da razlike između učenika i učenica, kada se radi o poremećajima u ponašanju postoje, a navedeno ukazuje na potrebu evidentiranja tih pokazatelja u školskom okruženju i uključivanja navedenih saznanja pri izradi različitih preventivnih programa uz omogućavanje različitih pristupa skupinama učenika i učenica.

Ključne riječi: poremećaji u ponašanju, učenici, učenice, škola, samoprocjena, Pula 